\title{
Regulatory uncertainties in the pharmaceutical sector: Perceptions among Nigerian pharmacists and policy implications for decision making
}

\author{
Emmanuel N. Anyika* \\ Department of Clinical Pharmacy and Biopharmacy, Faculty of Pharmacy, University of Lagos, Lagos, Nigeria
}

Received: December 31, 2015

DOI: $10.5430 /$ jha.v5n3p48

\author{
Accepted: January 24, 2016 \\ Online Published: March 7, 2016 \\ URL: http://dx.doi.org/10.5430/jha.v5n3p48
}

\begin{abstract}
Regulatory uncertainty (RU) is a component of general environmental uncertainties. Perceived regulatory uncertainties by Nigerian Pharmacists and policy implications were assessed using a questionnaire of 13-item inventory, self-administered to pharmacists in a captive situation during the Annual National Conference of the Pharmaceutical Society of Nigeria in November 2014. Participants were given the context of RU to avoid ambiguity and improve the quality of response. Six items addressed pharmacists' knowledge of impact of regulatory uncertainties in pharmacy practice; three addressed social regulation and policy issues in the pharmaceutical sector, three dealt with perceived policy implications, while one item was on demographic characteristics. Descriptive statistics was used to analyze the results. A total of 507 pharmacists comprising: 42 (8.28\%), $316(62.33 \%), 37(7.30 \%), 86(16.96 \%)$ and $26(5.13 \%)$ pharmacists in the industry, community, government (technocrats), hospital and academia respectively, completed the questionnaires. Vast majority (98\%, $92 \%$ respectively) indicated that inadequate legislative control would increase business risk and that RU within professional body could cause varied enforcement decisions. A total of $95 \%$ were aware of the involvement of other stakeholders in pharmacy practice. Majority (73\%) indicated correctly that an increase in RU would cause a decrease in predictability of law enforcement as well as a negative effect on the stimulation of investment in the pharmaceutical sector. Also a high majority recognized the role of politics on the outcomes in pharmaceutical sector. A high percentage (92.5\%) recognized that collaborative approach to policy making, and implementation would reduce acrimony and cost of social regulation, and increase the benefits of essential products. Some responses did not reflect in-depth understanding of the influence of RU on investment decisions and policy implications in Nigeria. These prompt the need to educate pharmacists on regulatory issues, the adaptation of policy options, market dynamics, and their stake in the complex pharmaceutical sector to enable them achieve greater control on the management of uncertainty. Structures, systems and strategies should be matched with political and financial resources, and policy guidelines to achieve laudable health outcomes. Models of relationships for achieving best regulatory practices are presented.
\end{abstract}

Key Words: Regulatory uncertainty, Pharmaceutical sector, Pharmacists' perceptions, Policy implications, Decision making

\section{INTRODUCTION}

Regulatory uncertainty (RU) is based on the institutional theory as a sub-concept of perceived environmental uncertainty, and addresses the inability of a company's decision maker to have a clear understanding of future regulations that will evolve in its environment. ${ }^{[1]}$ As organizations are obliged to respect the regulatory decisions, the regulatory environment is viewed as a way of exercising coercive power of regulatory

\footnotetext{
*Correspondence: Emmanuel N. Anyika; Email: emmaboogie22@yahoo.com; Address: Department of Clinical Pharmacy \& Biopharmacy, Faculty of Pharmacy, University of Lagos, Nigeria.
} 
agencies on organizations through supervision and market control over actors and their behavior. ${ }^{[2,3]}$ Uncertainty can result from different causes, which could originate from exogenous shocks, unforeseeable behavioral choices, or the two causes combined. ${ }^{[4]}$ General environmental uncertainties were classified by Miller ${ }^{[5]}$ into political, government policy, macroeconomic, social, and natural uncertainties. As uncertainty shifts from continuous (relatively stable environment with slow and steady changes) to discontinuous uncertainty characterized by uneven changes, the global regulatory landscape continues to evolve to ensure that pharmaceutical products are safe and effective. ${ }^{[6]}$ The FDA (US) approval process is associated with a high degree of uncertainty that complicates an innovator's ability to predict review times, pre- and post-approval requirements. ${ }^{[7]}$ The influence of RU on pharmaceutical investment decisions is two-fold: a negative impact resulting in additional cost - from transition cost perspective, which thrives organizations to wait or postpone projects until more information or clarity is gathered; ${ }^{[8]}$ or a positive impact of triggering investments to gain competitive advantage through the use of firm specific resources (resource-based strategy) or real option approach by gaining a right for a future larger investment. ${ }^{[6,9]}$

Drug regulation is the totality of all measures that governments take to ensure the quality of medicines as well as the relevance and accuracy of product information. ${ }^{[10]}$ The success or failure of drug regulation depends on the implementation, which has four dimensions: administrative elements, regulatory functions, technical components, and level of regulation. The political structure of any country determines the overall success of its drug regulation. ${ }^{[11]}$ Uncertainty in drug registration could lead to market related problems if companies delay their products entering the market place due the time required to scrutinize and approve fresh applications and new molecular entities (NME), the specific safety and efficacy requirements, which are different for each combination of diseases, drugs, and indications; with approval requiring multiple Food and Drug Administration (FDA) review cycles. ${ }^{[7,12]}$

Regulation of pharmaceutical sector touches the cords of divergent powerful interest groups in business and therefore, can be acrimonious particularly in the developing economies. ${ }^{[13]}$ The need for regulation becomes more urgent because of the increasing number of drugs available, globalization of the pharmaceutical industry and the threat posed by the circulation of substandard, harmful and counterfeit drugs, illicit medicines supply chains and illegal manufacturing facilities. ${ }^{[14,15]}$ In the developing countries where the bulk of pharmaceutical products are imported, and where governments often establish weak regulatory institutions, processes and structures to control pharmaceutical products manufacturing, distribution and prescribing, and where the existence of cartels built on free enterprise is the norm rather than the exception, ${ }^{[13]} \mathrm{RU}$ in such environments is bound to be discontinuous. When power is diffused, political activity such as bargaining and coalition-building intensifies in the course of trying to resolve the issues. On the contrary, when power is centralized, there is higher probability that less politics will be involved in resolving conflicts.

Regulations are either social or economic in nature. Social regulations focus on the issues that affect the lives and welfare of the citizenry more directly, which set them at collision course with regulated industries. Related regulatory agencies in Nigeria include: National Agency for Food and Drug Administration and Control (NAFDAC), National Drug Law Enforcement Agency (NDLEA), Standards Organization of Nigeria (SON), National Institute for Pharmaceutical Research and Development (NIPRD) and National Environmental Safety Regulatory Authority (NESREA). The Pharmacists Council of Nigeria (PCN) is a professional body that regulates pharmacy practice in Nigeria with social regulatory functions too. Social regulations and social governance under environmental uncertainties are geared towards regulatory excellence and positive health outcomes (see Figure 1 and Figure 2). The pharmaceutical industry is partly a social welfare industry, which cannot be left entirely on the free market enterprise and the principles of demand and supply that drive it. The products are life-saving and sought by people of different economic status. Product quality, accessibility and affordability are crucial, which should be regulated by government that has directly or indirectly funded research and development as well as granting monopolies in the pharmaceutical sector. ${ }^{[16]}$ The pharmaceutical industry is also very susceptible to fraud and corruption. Health uncertainty arises especially through the distribution network due to the asymmetry of information between the care providers in the supply chain (manufacturers, marketers and health professionals), and the final consumer (patient or client). The problems of transparency and accountability as well as agency capture are high when regulatory staff can exercise a lot of discretionary powers due to weak legislation and regulatory uncertainties. ${ }^{[17]}$

\section{Objectives of the study}

The objectives of this study are to assess: (1) How informed pharmacists are (as decision makers) on the impact of regulatory uncertainties in pharmacy practice; (2) How pharmacists perceive social regulation and decision-making in the pharmaceutical sector; (3) The policy implications of social regulation and social governance in the pharmaceutical sector under uncertainty. 


\section{MATERIALS AND METHODS}

The researcher developed a 13-item inventory. This inventory was validated by an Associate Professor of strategic management in the University of Lagos, who made necessary adjustments and corrections in the research instrument. The reliability test was ascertained through pilot-testing using pharmacists undergoing their M.Sc programmes in the Faculty of Pharmacy, University of Lagos. The approved inventory was self-administered in a captive situation (during a plenary session) to pharmacists who attended the Annual National Conference of the Pharmaceutical Society of Nigeria in November 2014. Participants comprising pharmacists in different practice areas were given the context of RU to avoid ambiguity and improve on the quality of response. The research questions assessed to what extent pharmacists in different practice areas understood RU, and policy implications of RU in pharmacy practice. Six questions addressed perceptions; three questions each addressed perceived social regulation and policy implications respectively, while one question was on demographics. The completed questionnaires were collated and analyzed using SPSS version 21.0. Descriptive statistics were also used for the analyses of the results. Inferential statistics in the comparison of the perceptions of pharmacists in different practice areas may not add much value to the outcomes, hence were not used.

\section{RESUlts}

The results of the three questions are presented in the tables below. Table 1A presents the background information on pharmacists' awareness as decision makers, of the impact of regulatory uncertainties in pharmacy practice. Table 1B shows the details of the means, standard deviations and relative indices based on the five practice areas. Table $2 \mathrm{~A}$ shows the pharmacists' perceptions of social regulation and decision-making in the pharmaceutical sector. The details of the comparative results in the five practice areas are presented in Table 2B. The policy implications of social regulation and social governance in the pharmaceutical sector are presented in Table 3A; with further analyses based on the practice areas presented in Table 3B. Also models of relationship between environmental uncertainties, drug regulatory structures, the pharmaceutical sub-systems and health outcomes on the one hand (see Figure 1); and the regulatory excellence in the pharmaceutical sector under environmental uncertainties on the other (see Figure 2) are presented.

\section{DISCUSSION AND CONCLUSION}

Regulatory complexity and policy uncertainty continue to exert enormous impact in developing economies as the health sector grapples to cope with regulatory overreach in some advanced countries. ${ }^{[18]}$ The analyses of pharmacists' awareness of the impact of RU in the areas of risk of inadequate legislative control, law enforcement decisions, stakeholders and scope of operation were carried out. About $98 \%$ of all pharmacists opined that inadequate legislative control in pharmacy practice would increase business risk while only $2 \%$ said that there would be a decrease in business risk. However RU has a two-fold impact on investment decisions (positive or negative) based on the findings of Luo, ${ }^{[8]}$ and Rugman \& Verbeke. ${ }^{[9]}$ There is need for pharmacists to be fully aware of the two-fold implications to be able to make more informed decisions. About $92 \%$ of all participants reported that only two organizations (NAFDAC and PCN) exert regulatory control in the pharmaceutical sector. In recent times, the other regulatory agencies indicated by less than $8 \%$ of the pharmacists play minor roles in the drug regulation, with some overlap functions when their activities are not well coordinated. Majority of the participants $(80.5 \%)$ opined that RU within a regulatory body could cause postponement, reduction or cancellation of law enforcement decisions. This was corroborated by Lessard ${ }^{[4]}$ who reported that uncertainty could result from different causes, ranging from exogenous shocks, unforeseeable behavioral causes or a combination of the two factors (see Table 1A).

Majority of the pharmacists (95.7\%) showed awareness that there were other stakeholders in the drug distribution network. This awareness is important for initiating and ensuring effective collaboration of all stakeholders, for sustainable social regulation in the pharmaceutical sector. It also creates an enabling environment for regulatory policies that will be scientifically sound, socially desirable and politically expedient (as indicated by $97.4 \%$ of the respondents) with minimal acrimony. ${ }^{[13]}$ Only $52.5 \%$ of the respondents were well informed about the right ports of entry (air and sea ports) for imported pharmaceuticals into the country. There is need for continuing education in forensic sciences and drug regulations, to bridge the information gap. Table 1B shows how informed the participants are on the impact of regulatory uncertainties within the practice areas. Pharmacists in the industry and community/ wholesale pharmacists seem to be more informed than pharmacists in hospitals, academia and governments, with high relative index greater than 1.0. The findings may be due to the impact of the environment and constant exposure to the regulatory uncertainties by these groups of practitioners compared to the participants in other practice areas with lower relative indices.

From the results in Table 2A, $73 \%$ of the participants correctly indicate that if $\mathrm{RU}$ increases, the predictability of law enforcement will decrease. A vast majority (93.7\%) opined that RU would have a negative effect on the stimulation of in- 
vestment in the pharmaceutical sector. However as decision to achieve the desirable social regulation in the sector where makers, pharmacists should position their organizations to some of the regulated are powerful and very influential in take advantage of the resource-based strategy or real option approach $^{[6]}$ and invest even when uncertainty is high. Also 97.8\% of pharmacists recognize the importance of politics on the outcomes in the pharmaceutical sector. Pharmacists should therefore be prepared to play the politics necessary developing economies. Pharmacists in the industry, government and community/wholesale sub-sectors seem to be more conscious of the role of social regulation in pharmacy practice (with relative index $>1.0$ in Table $2 \mathrm{~B}$ ).

Table 1. Research Question 1: How informed are pharmacists as decision makers on the impact of regulatory uncertainties in pharmacy practice?

\begin{tabular}{|c|c|c|c|c|c|c|c|c|c|c|c|c|c|}
\hline \multirow[t]{2}{*}{ Variable } & \multirow[t]{2}{*}{ Characteristics } & \multicolumn{2}{|c|}{$\begin{array}{l}\text { Academia } \\
(\mathrm{N}=\mathbf{2 6})\end{array}$} & \multicolumn{2}{|c|}{$\begin{array}{l}\text { Community/ } \\
\text { Wholesale } \\
(\mathrm{N}=316)\end{array}$} & \multicolumn{2}{|c|}{$\begin{array}{l}\text { Hospital } \\
(\mathrm{N}=\mathbf{8 6})\end{array}$} & \multicolumn{2}{|c|}{$\begin{array}{r}\text { Industry } \\
(\mathrm{N}=42)\end{array}$} & \multicolumn{2}{|c|}{$\begin{array}{l}\text { Government/ } \\
\text { Others }(\mathrm{N}=37)\end{array}$} & \multicolumn{2}{|c|}{$\begin{array}{l}\text { Pooled } \\
(\mathrm{N}=507)\end{array}$} \\
\hline & & Freq & $\%$ & Freq & $\%$ & Freq & $\%$ & Freq & $\%$ & Freq & $\%$ & Freq & $\%$ \\
\hline \multirow{2}{*}{$\begin{array}{l}\text { The risk of inadequate } \\
\text { legislative control in } \\
\text { pharmacy practice will: }\end{array}$} & Decrease Business Risk & 0 & 0 & 0 & 0 & 10 & 12 & 0 & 0 & 0 & 0 & 10 & 2.0 \\
\hline & Increase Business Risk & 26 & 100 & 316 & 100 & 76 & 88 & 42 & 100 & 37 & 100 & 497 & 98 \\
\hline \multirow{5}{*}{$\begin{array}{l}\text { Organization(s) that } \\
\text { exert(s) regulatory } \\
\text { control in the } \\
\text { pharmaceutical sector } \\
\text { is (are): }\end{array}$} & NAFDAC & 7 & 26.9 & 0 & 0 & 4 & 4.7 & 2 & 4.8 & 9 & 24.3 & 22 & 4.3 \\
\hline & PCN & 1 & 3.8 & 0 & 0 & 6 & 7.0 & 1 & 2.4 & 0 & 0 & 8 & 1.6 \\
\hline & SON & 1 & 3.8 & 0 & 0 & 2 & 2.3 & 0 & 0 & 0 & 0 & 3 & 0.6 \\
\hline & NDLEA & 4 & 15.4 & 0 & 0 & 1 & 1.2 & 0 & 0 & 1 & 2.7 & 6 & 1.2 \\
\hline & A and B only & 13 & 50.0 & 316 & 100 & 73 & 84.9 & 39 & 92.9 & 27 & 73.0 & 468 & 92.3 \\
\hline \multirow{5}{*}{$\begin{array}{l}\text { Regulatory uncertainty } \\
\text { in a regulatory body } \\
\text { will cause the } \\
\text { following effect(s) on } \\
\text { law enforcement } \\
\text { decisions: }\end{array}$} & Postponement & 5 & 19.2 & 7 & 2.2 & 19 & 22.1 & 2 & 4.8 & 12 & 32.4 & 45 & 8.9 \\
\hline & Reduction & 8 & 30.8 & 1 & 0.3 & 10 & 11.6 & 2 & 4.8 & 0 & 0 & 21 & 4.1 \\
\hline & Cancellation & 3 & 11.5 & 0 & 0 & 24 & 27.9 & 3 & 7.1 & 1 & 2.7 & 31 & 6.1 \\
\hline & All of the above & 10 & 38.5 & 308 & 97.5 & 32 & 37.2 & 35 & 83.3 & 23 & 62.2 & 408 & 80.5 \\
\hline & None of the above & 0 & 0 & 0 & 0 & 1 & 1.2 & 0 & 0 & 1 & 2.7 & 2 & 0.4 \\
\hline \multirow{2}{*}{$\begin{array}{l}\text { Pharmacists are the } \\
\text { only stakeholders in } \\
\text { drug distribution }\end{array}$} & False & 20 & 76.9 & 316 & 100 & 73 & 84.9 & 39 & 92.9 & 37 & 100 & 485 & 95.7 \\
\hline & True & 6 & 23.1 & 0 & 0 & 13 & 15.1 & 3 & 7.1 & 0 & 0 & 22 & 4.3 \\
\hline \multirow{5}{*}{$\begin{array}{l}\text { For pharmacy } \\
\text { regulation (policy) to } \\
\text { be sustainable, it must } \\
\text { be: }\end{array}$} & $\begin{array}{l}\text { Scientifically and } \\
\text { technically sound }\end{array}$ & 2 & 7.7 & 0 & 0 & 5 & 5.8 & 0 & 0 & 0 & 0 & 7 & 1.4 \\
\hline & socially desirable & 1 & 3.8 & 0 & 0 & 0 & 0 & 0 & 0 & 0 & 0 & 1 & 0.2 \\
\hline & politically expedient & 2 & 7.7 & 0 & 0 & 3 & 3.5 & 0 & 0 & 0 & 0 & 5 & 1.0 \\
\hline & all of above & 16 & 61.5 & 3 & 0.9 & 74 & 86.0 & 8 & 19.0 & 37 & 100 & 138 & 27.2 \\
\hline & A and B only & 5 & 19.2 & 313 & 99.1 & 4 & 4.7 & 34 & 81.0 & 0 & 0 & 356 & 70.2 \\
\hline \multirow{5}{*}{$\begin{array}{l}\text { NAFDAC allows the } \\
\text { importation of drugs } \\
\text { and other regulated } \\
\text { products through the } \\
\text { following: }\end{array}$} & designated sea ports & 0 & 0 & 0 & 0 & 1 & 1.2 & 0 & 0 & 0 & 0 & 1 & 0.2 \\
\hline & designated airports & 0 & 0 & 0 & 0 & 2 & 2.3 & 0 & 0 & 0 & 0 & 2 & 0.4 \\
\hline & land borders & 0 & 0 & 0 & 0 & 1 & 1.2 & 0 & 0 & 0 & 0 & 1 & 0.2 \\
\hline & all of the above & 17 & 65.4 & 169 & 53.5 & 43 & 50.0 & 2 & 4.8 & 6 & 16.2 & 237 & 46.7 \\
\hline & A and B only & 9 & 34.6 & 147 & 46.5 & 39 & 45.3 & 40 & 95.2 & 31 & 83.8 & 266 & 52.5 \\
\hline
\end{tabular}

Note. Source: Field Survey 2014; Sample size = 507; NAFDAC: National Agency for Food and Drug Administration and Control; PCN: Pharmacists Council of Nigeria; SON: Standards Organization of Nigeria; NDLEA: National Drug Law Enforcement Agency

B. How informed are pharmacists as decision makers on the impact of regulatory uncertainties in pharmacy practice?

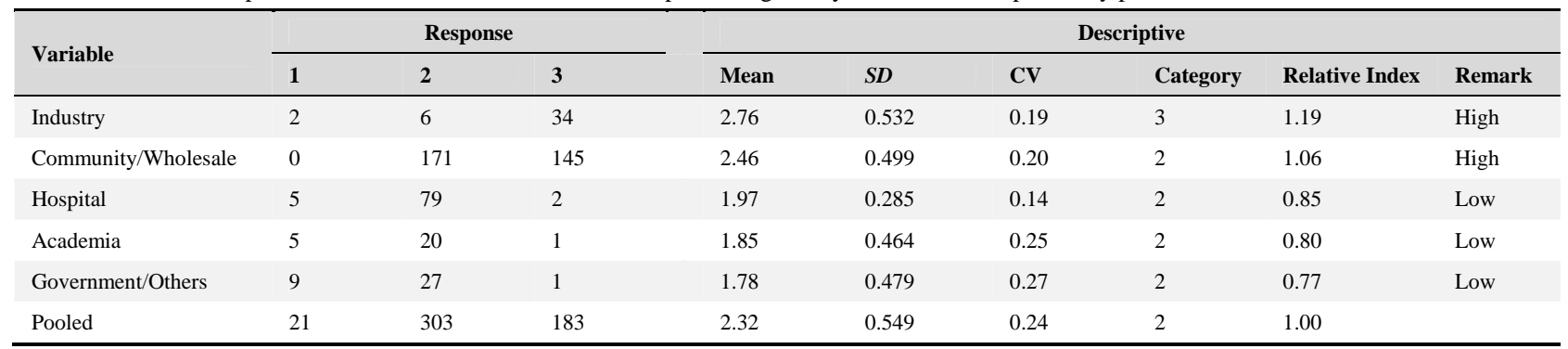

Note. Source: Field Survey 2014: Not Informed (1); Moderately Informed (2); Highly Informed (3) 
Table 2. Research Question 2: How do pharmacists perceive social regulation and decision-making in the pharmaceutical sector?

A: Analysis of Research Question 2

\begin{tabular}{|c|c|c|c|c|c|c|c|c|c|c|c|c|c|}
\hline \multirow[t]{2}{*}{ Variable } & \multirow[t]{2}{*}{ Characteristics } & \multicolumn{2}{|c|}{$\begin{array}{l}\text { Academia } \\
(\mathrm{N}=\mathbf{2 6})\end{array}$} & \multicolumn{2}{|c|}{$\begin{array}{l}\text { Community/ } \\
\text { Wholesale } \\
(\mathrm{N}=316) \\
\end{array}$} & \multicolumn{2}{|c|}{$\begin{array}{l}\text { Hospital } \\
(\mathrm{N}=\mathbf{8 6})\end{array}$} & \multicolumn{2}{|c|}{$\begin{array}{l}\text { Industry } \\
(\mathrm{N}=42)\end{array}$} & \multicolumn{2}{|c|}{$\begin{array}{l}\text { Government/Ot } \\
\text { hers }(N=37)\end{array}$} & \multicolumn{2}{|c|}{$\begin{array}{l}\text { Pooled } \\
(N=507)\end{array}$} \\
\hline & & Freq & $\%$ & Freq & $\%$ & Freq & $\%$ & Freq & $\%$ & Freq & $\%$ & Freq & $\%$ \\
\hline \multirow{2}{*}{$\begin{array}{l}\text { If regulatory uncertainty } \\
\text { increases, the predictability of } \\
\text { law enforcement: }\end{array}$} & Decreases & 20 & 76.9 & 226 & 71.5 & 78 & 90.7 & 29 & 69.0 & 17 & 45.9 & 370 & 73.0 \\
\hline & Increases & 6 & 23.1 & 90 & 28.5 & 8 & 9.3 & 13 & 31.0 & 20 & 54.1 & 137 & 27.0 \\
\hline \multirow{2}{*}{$\begin{array}{l}\text { Regulatory uncertainty can } \\
\text { trigger investments in } \\
\text { pharmaceutical sector }\end{array}$} & False & 23 & 88.5 & 304 & 96.2 & 74 & 86.0 & 42 & 100 & 32 & 86.5 & 475 & 93.7 \\
\hline & True & 3 & 11.5 & 12 & 3.8 & 12 & 14.0 & 0 & 0 & 5 & 13.5 & 32 & 6.3 \\
\hline \multirow{2}{*}{$\begin{array}{l}\text { Politics plays a significant } \\
\text { role in outcomes of regulation } \\
\text { of pharmaceutical sector }\end{array}$} & False & 3 & 11.5 & 316 & 100 & 5 & 5.8 & 0 & 0 & 3 & 8.1 & 11 & 2.2 \\
\hline & True & 23 & 88.5 & 0 & 0 & 81 & 94.2 & 42 & 100 & 34 & 91.9 & 496 & 97.8 \\
\hline
\end{tabular}

Note. Source: Field Survey 2014; Sample size $=507$

B. How do pharmacists perceive social regulation and decision-making in the pharmaceutical sector?

\begin{tabular}{|c|c|c|c|c|c|c|c|c|}
\hline \multirow{2}{*}{ Variable } & \multicolumn{2}{|c|}{ Response } & \multicolumn{6}{|c|}{ Descriptive } \\
\hline & $\mathbf{0}$ & 1 & Mean & $S D$ & CV & Category & Relative Index & Remark \\
\hline Community/Wholesale & 0 & 316 & 1.00 & 0.000 & 0.00 & 1 & 1.01 & High \\
\hline Industry & 0 & 42 & 1.00 & 0.000 & 0.00 & 1 & 1.01 & High \\
\hline Government/Others & 0 & 37 & 1.00 & 0.000 & 0.00 & 1 & 1.01 & High \\
\hline Hospital & 5 & 81 & 0.94 & 0.235 & 0.25 & 1 & 0.95 & Low \\
\hline Pooled & 7 & 500 & 0.99 & 0.117 & 0.12 & 1 & 1.00 & \\
\hline
\end{tabular}

Source: Field Survey 2014: Decrease (0); Increase (1)

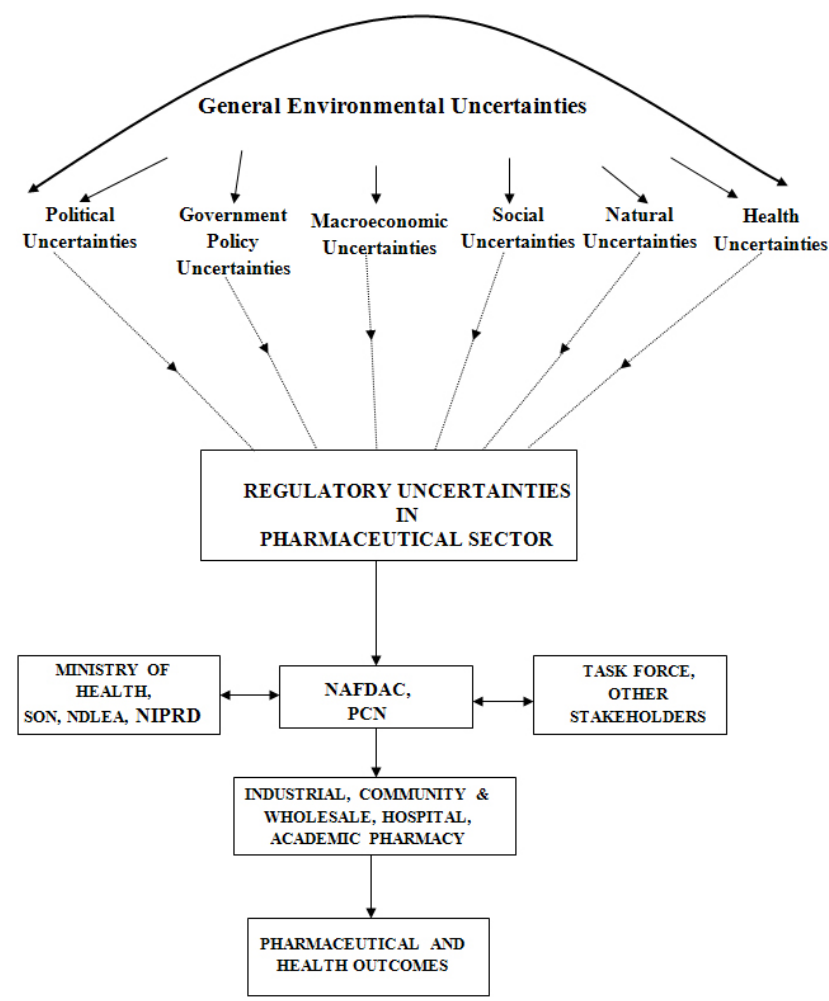

Figure 1. Relationship between environmental uncertainties, drug regulatory structures, pharmaceutical sub-systems \& health outcomes

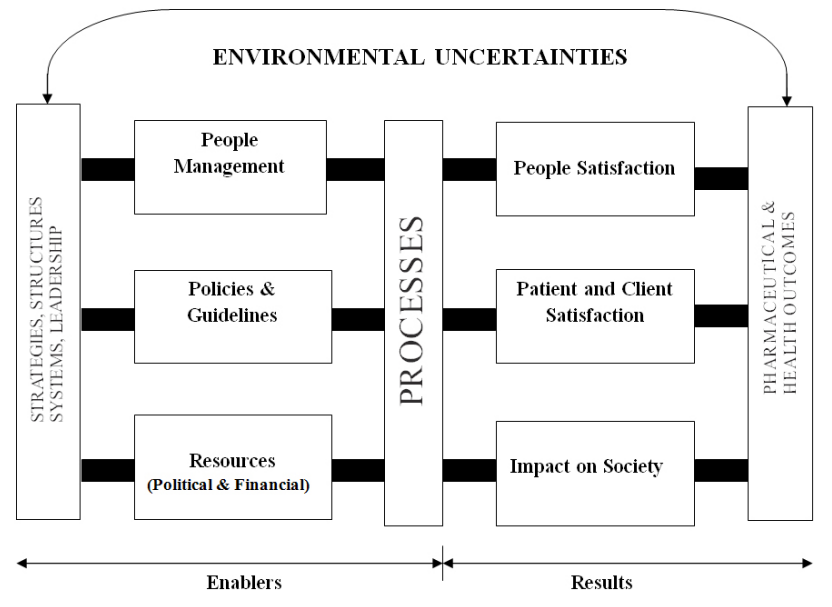

Figure 2. Regulatory excellence in pharmaceutical sector under environmental uncertainties Adapted from: business excellence model, ${ }^{[20]}$ and regulatory excellence model ${ }^{[11]}$

Policy implications of social regulation and social governance in the pharmaceutical sector under environmental uncertainty (see Table 3A and Table 3b) include the overwhelming recognition by $99 \%$ of the pharmacists, that RU will impede investment in the pharmaceutical sector. Also $96.6 \%$ of participants recognize that weak enforcement of drug laws would increase RU, while $92.5 \%$ appreciate that collaborative approach to policy making and implementation would 
reduce acrimony, reduce cost of social regulation and in- areas, with community pharmacists and those in government crease the benefits of essential products. These impacts were having a slight edge with relative index $>1.0$ (see Table 3B). evenly acknowledged by pharmacists in different practice

Table 3. Research Question 3: What are the policy implications of social regulation and social governance in the pharmaceutical sector under uncertainty?

A. Analysis of Research Question 3

\begin{tabular}{|c|c|c|c|c|c|c|c|c|c|c|c|c|c|}
\hline \multirow[t]{2}{*}{ Variable } & \multirow[t]{2}{*}{ Characteristics } & \multicolumn{2}{|c|}{$\begin{array}{l}\text { Academia } \\
(\mathrm{N}=\mathbf{2 6})\end{array}$} & \multicolumn{2}{|c|}{$\begin{array}{l}\text { Community/ } \\
\text { Wholesale } \\
(\mathrm{N}=316) \\
\end{array}$} & \multicolumn{2}{|c|}{$\begin{array}{l}\text { Hospital } \\
\text { (N = 86) }\end{array}$} & \multicolumn{2}{|c|}{$\begin{array}{l}\text { Industry } \\
(\mathrm{N}=42)\end{array}$} & \multicolumn{2}{|c|}{$\begin{array}{l}\text { Government/ } \\
\text { Others }(\mathbf{N}=37)\end{array}$} & \multicolumn{2}{|c|}{$\begin{array}{l}\text { Pooled } \\
(\mathrm{N}=507)\end{array}$} \\
\hline & & Freq & $\%$ & Freq & $\%$ & Freq & $\%$ & Freq & $\%$ & Freq & $\%$ & Freq & $\%$ \\
\hline \multirow{2}{*}{$\begin{array}{l}\text { RU can impede } \\
\text { investment in } \\
\text { pharmaceutical } \\
\text { sector: }\end{array}$} & False & 0 & 0 & 0 & 0 & 3 & 3.5 & 0 & 0 & 2 & 5.4 & 5 & 1.0 \\
\hline & True & 26 & 100 & 316 & 100 & 83 & 96.5 & 42 & 100 & 35 & 94.6 & 502 & 99.0 \\
\hline \multirow{3}{*}{$\begin{array}{l}\text { Weak enforcement } \\
\text { of drug laws: }\end{array}$} & No Impact & 3 & 11.5 & 0 & 0 & 5 & 5.8 & 2 & 4.8 & 0 & 0 & 10 & 2.0 \\
\hline & $\begin{array}{l}\text { Decreases Regulatory } \\
\text { Uncertainty }\end{array}$ & 23 & 88.5 & 316 & 100 & 74 & 86.0 & 40 & 95.2 & 37 & 100 & 490 & 96.6 \\
\hline & $\begin{array}{l}\text { Increases Regulatory } \\
\text { Uncertainty }\end{array}$ & 0 & 0 & 0 & 0 & 7 & 8.1 & 0 & 0 & 0 & 0 & 7 & 1.4 \\
\hline \multirow{5}{*}{$\begin{array}{l}\text { Collaborative } \\
\text { approach to policy } \\
\text { making and } \\
\text { implementation } \\
\text { will: }\end{array}$} & $\begin{array}{l}\text { Reduce acrimony in } \\
\text { distribution network }\end{array}$ & 3 & 11.5 & 0 & 0 & 11 & 12.8 & 2 & 4.8 & 1 & 2.7 & 17 & 3.4 \\
\hline & $\begin{array}{l}\text { Reduce cost of social } \\
\text { regulation }\end{array}$ & 3 & 11.5 & 0 & 0 & 0 & 0 & 0 & 0 & 0 & 0 & 3 & 0.6 \\
\hline & $\begin{array}{l}\text { Increase benefits of } \\
\text { essential products }\end{array}$ & 2 & 7.7 & 0 & 0 & 4 & 4.7 & 0 & 0 & 0 & 0 & 6 & 1.2 \\
\hline & All of the above & 18 & 69.2 & 304 & 96.2 & 71 & 82.6 & 40 & 95.2 & 36 & 97.3 & 469 & 92.5 \\
\hline & None of the above & 0 & 0 & 12 & 3.8 & 0 & 0 & 0 & 0 & 0 & 0 & 12 & 2.4 \\
\hline
\end{tabular}

Note. Source: Field Survey 2014. Sample size $=507$

B. Policy implications of social regulation and social governance in the pharmaceutical sector under uncertainty

\begin{tabular}{|c|c|c|c|c|c|c|c|c|c|}
\hline \multirow{2}{*}{ Variable } & \multicolumn{3}{|c|}{ Response } & \multicolumn{6}{|c|}{ Descriptive } \\
\hline & 1 & 2 & 3 & Mean & $S D$ & $\mathrm{CV}$ & Category & Relative Index & Remark \\
\hline Community/Wholesale & 0 & 0 & 316 & 2.00 & 0.000 & 0.00 & 2 & 1.02 & High \\
\hline Government/Others & 0 & 1 & 36 & 1.97 & 0.164 & 0.08 & 2 & 1.01 & High \\
\hline Industry & 0 & 2 & 40 & 1.95 & 0.216 & 0.11 & 2 & 0.99 & Low \\
\hline Hospital & 1 & 11 & 74 & 1.85 & 0.392 & 0.21 & 2 & 0.94 & Low \\
\hline Academia & 0 & 6 & 20 & 1.77 & 0.430 & 0.24 & 2 & 0.90 & Low \\
\hline Pooled & 1 & 20 & 486 & 1.96 & 0.213 & 0.11 & 2 & 1.00 & \\
\hline
\end{tabular}

Note. Source: Field Survey 2014: No Impact (1); Decrease Regulatory Uncertainty (2); Increase Regulatory Uncertainty (3)

\subsection{The models}

Figure 1: RU is a component of general environmental uncertainties - made up of political, government policy, macroeconomic, social and natural uncertainties. ${ }^{[5]}$ RU in the pharmaceutical sector is a component of the probability, ambiguity and complexity in the health care delivery system. As a discontinuous uncertainty, any single regulatory decision can change the pharmacy practice landscape and the business environment. Democratic changes in government, government policy reforms, and security issues will affect regulatory changes in the practice environment. Other natural variations of uncertainty like the recent outbreak of Ebola pandemic in some West African countries are exogenous shocks, which could cause upheavals in the health sector in general, with resultant uncertainty in vaccines production and R\&D efforts to cope with the challenges. NAFDAC and

Published by Sciedu Press
PCN play regulatory roles of quality assurance and control of food substances and drugs imported through air and sea ports, as well as those manufactured in the country using the enabling government regulations. These are supported by the Federal and state ministries of health, NDLEA, SON, NIPRD, Nigerian Ports Authority (NPA), Federal Environmental Protection Agency (FEPA), National Environmental Standard and Regulation Enforcement Agency (NESREA), Consumer Protection Council (CPC) and the task force (usually Joint Task Force of the police, the military personnel and others). Other stakeholders usually neglected by the professional groups in the developing economies include the divergent powerful interests in the pharmaceutical business sector, comprising the cartels(the regulated) built earlier on free enterprise, and who are more experienced than the regulators in the uncertain business environment. The pharma- 
ceutical sector comprises the five practice areas of pharmacy, whose members play crucial roles in the operation of the pharmaceutical system. The overall level of professionalism practiced culminates in the perceived pharmaceutical and health outcomes. ${ }^{[19]}$

Figure 2: The Regulatory excellence model in the pharmaceutical sector is an adaptation of the Business Excellence Model, ${ }^{[20]}$ and The Regulatory Excellence Model. ${ }^{[11]}$ Under environmental uncertainties, strategies, structures, systems and leadership are combined through effective human resources management, financial and material resources and enabling policies. These inputs undergo series of transformation under different regulatory uncertainties and complexities that exist in different operational environments to give varying degrees of patient and client satisfaction; and subsequently, variable impact to the society through the pharmaceutical and health outcomes. Under the prevailing environmental uncertainties, the achievement of regulatory excellence in the pharmaceutical sector and service delivery will depend on the effective balancing of scientific uncertainty (level of funding R\&D efforts in the industry and academia), RU (resulting from specific safety and efficacy requirements and timelines), coverage uncertainty (as a result of the shift in the insurance landscape and financial risks from payers more to providers), policy and implementation uncertainties(resulting from uncertain returns on investment and uncertainty in patent challenges from similar products after investments in $R \& D)$.

In dealing with RU, pharmacists as decision makers should apply Moore's (2012) framework ${ }^{[21]}$ to help their organizations through: environmental scanning for emergent opportunities and threats; developing and applying risk appetite to business activities; undertaking causal factor and failure mode analyses in their practice areas; independent investigation of serious incidents; restoration of confidence in the presence of uncertainty; risk and safety management; and board politics.

\subsection{Limitations}

The study was limited to only pharmacists that attended the National Conference of PSN, 2014.

\subsection{Strengths}

The study captured the perceptions of a cross section of pharmacists from all over the federation and in different practice areas who attended the National Conference.

\section{ACKNOWLEDGEMENTS}

The author acknowledges the pharmacists who completed the research instruments during the plenary session of the Annual Conference of the Pharmaceutical Society of Nigeria. The research was funded by the author.

\section{CONFlicts OF INTEREST Disclosure}

The author declares that there are no competing interests.

\section{REFERENCES}

[1] Schwarks B. Influence of regulatory uncertainty on capacity investments- Are investments in new technologies a risk mitigation measure? 2009 [5 October 2014, date last accessed]. Available from: https://www.infraday.tu-berlin.de/fileadmin/fg280 /veranstartungen/infraday/conference_2009/papers_p resentation

[2] Scott WR. Institutions and organizations. Ideas and Interests. $3^{\text {rd }}$ ed. Sage Publications, Los Angeles, CA.

[3] Eberlein B, Grande E. Beyond delegation: transnational regulatory regimes and the EU regulatory state. Journal of European Public Policy. 2005; 12(1): 89-112. http://dx.doi.org/10.1080/135 0176042000311925

[4] Lessard DR. Country risk and the structure of international financial intermediation. In CC. Stone (ed). Financial risk: theory evidence and implications Boston, Mass, Kluwer Academic Publisher; 1988. 200-230.

[5] Miller KD. A framework for integrated risk management in international business. Journal of International Business Studies. 1992; 23(2): 311-331. http://dx.doi.org/10.1057/palgrave.ji bs . 8490270

[6] Doh JP, Pearce JA. Corporate entrepreneurship and real options in transitional policy environments: theory development. Journal of
Management Studies 2004; 41(4): 645-664. http://dx.doi.org /10.1111/j.1467-6486.2004.00448.x

[7] Lesser N, Mulder J, Terry C, et al. In the face of uncertainty: a challenging future for biopharmaceutical innovation. Deloitte Development LLC. 2014 [15 July 2015, date last accessed]. Available from: www.deloitte.com/us/LifeSciencesConsulting

[8] Luo Y. Building a strong foothold in an emerging market: a link between resource commitment and environmental conditions. Journal of Management Studies 2004; 41(5): 749-773. http://dx. doi.o $\mathrm{rg} / 10.1111 / \mathrm{j} .1467-6486.2004 .00452 . \mathrm{x}$

[9] Rugman AM, Verbeke A. Corporate Strategies and environmental regulations: an organizing framework. Strategic Management Journal. 1998; 19(4): 363-375. http://dx.doi.org/10.1002/(SICI ) 1097-0266 (199804) 19:4<363: : AID-SMJ974>3.0.CO;2-H

[10] Ratanawijitrasin S, Wondemagegnehu E. Effective drug regulation: a multi-country study. World Health Organization. 2002 [20 February 2015, date last accessed]. Available from: www. apps.who.int/i ris/handle/10665/42470

[11] Dike ON, Onah JO. A partnership model for the control of unethical marketing of drugs in Nigeria. European Journal of Business and Management. 2013; 5(29). Available from: www .iiste.org

[12] Anyika EN. Challenges of implementing sustainable health care delivery in Nigeria under environmental uncertainty. Journal of 
Hospital Administration. 2014; 3(6): 113-126. Available from: www.sciedu.ca/jha

[13] Olugbenga EO. The politics of pharmaceutical regulation in Nigeria: policy options for third world countries. Public Policy and Administration Research. 2013; 3(8): 89-100. Available from: www.iiste.org

[14] Asfaw A, Gustafsson-Wright E, Vander Gaag J. Willingness to pay for health insurance: An analysis of the potential market for new low-cost health insurance products in Namibia, Amsterdam Institute for International Development. 2008; 1-22. PMid: 23057308. http://dx.doi.org/10.4314/eamj.v87i3.62200

[15] Kahn U, Kreutzer S, Gill J, et al. Falsified medicines and the global public's health. Report of the regional taskforce on the prevention and control of substandard/ spurious/ falsely labeled/ falsified/ counterfeit medicines. WHO Regional Office for Africa 2011. 2012: 1-20. Available from: www.if pma.org/uploads/media/UCL-M atrix_Insight_Falsified_Medicines_and_the_Global_P ublics_Health.pdf

[16] Angell M. Pharmaceutical myths. Financial Standard (Monday, July 17). 2006 (Olugbenga op. cit.).
[17] Lane JE. The public Sector: concepts, models and approaches. London: SAGE Publications Ltd.; 2000.

[18] Davis SJ. Regulatory complexity and policy uncertainty: headwinds of our own making. Delivered at the Hillsdale College Free Market Forum on "Markets, Government, and the Common Good" in Omaha, Nebraska. 2015: 15-17. Available from: http://faculty.chicag obooth.edu/steven.davis/

[19] Anyika EN. Systems approach to pharmacy practice (iceberg model) and mechanism of professional extinction. West African Journal of Pharmacy. 1998; 12(2): 6-12.

[20] Oakland JS. Total Quality Management (TQM). In The IEBM Encyclopedia of Marketing. London: MJ. Baker Thomson Learning. 1999. Available from: www.bpir.com/total-quality-managem ent-business-excellence-models-bpir.com.html

[21] Moore PA. A comparative multi-method case study to identify features of organizational governance in common in those English NHS acute providers subject to regulatory intervention. A dissertation submitted to The University of Manchester, Manchester Business School. 2012. In Moore P. Countering the biggest risk of all: attempting to govern uncertainty in health care management. Good Governance Institute. 2013. Available from: www.goog-governance.org.uk 